\title{
The CORE Model for Improving students behavior and learning outcomes the production technology development of Social Sciences Learning
}

\section{Gilang Maulana Jamaludin}

Faculty of Islamic Studies, Universitas Majalengka, Majalengka, West Java, Indonesia

gilangmaulana@gmail.com

\section{Muhammad Iqbal Al Ghozali}

IAI Bunga Bangsa Cirebon, West Java, Indonesia alghazalimuhammad0@gmail.com

\section{Rifki Fauzi}

STKIP Sebelas April Sumedang, West Java, Indonesia rifkifauzi@gmail.com

\begin{abstract}
Social studies subjects are one of the subjects that are not liked because the learning context is too monotonous containing memorization and readings that make the learning process saturated. This study aims to determine the increase in social studies activities and learning outcomes in the development of production technology by applying the Connecting Organizing Reflecting Extending (CORE) learning model. This study used the Classroom Action Research (CAR) or Penelitian Tindakan Kelas (PTK) method by Kemmis and Mc.Taggart models. The results of this study were in the first cycle of student activity aspects of visual activities $71.8 \%$ (good), aspects of oral activities $69.2 \%$ (good criteria), and aspects of listening activities $77 \%$ (good). In the second cycle, there was an increase namely the students' activities visual aspects to $83.3 \%$ (very good), aspects of oral activities $81.4 \%$ (very good), and aspects of listening activities $83.3 \%$ (very good). For the final test results, students also experienced an increase. The magnitude of the increase in the percentage of mastery learning from the initial data to the first cycle increased from
\end{abstract}


$46.1 \%$ to $69.2 \%$, while from the first cycle to the second cycle an increase from $69.2 \%$ to $92.3 \%$ of students who completed. Thus, it can be stated that the CORE model can improve student learning outcomes towards social studies learning on the material development of production technology in fourth-grade students at SDN Salamjajar, Cisitu District, Sumedang region.

Keywords: learning outcomes, CORE methods, social sciences, elementary school.

\section{INTRODUCTION}

In the implementation of education in schools there are three interrelated variables. The three variables are curriculum, teacher, and teaching and learning process. Curriculum development in Indonesia has been amended several times. Starting from the 1975 curriculum to the 2013 curriculum which has begun to be implemented in schools. The curriculum is a rule that is used in learning activities to achieve educational goals. The curriculum is a plan and arrangements that can use to manage learning activities and educational goals (Maulana: 2011).

Besides, teachers have an important position in the implementation of education. Under what was stated to Fahdini et al (2014) that the component that is considered the most important in learning activities is the role of a teacher. A teacher must lead the curriculum and transform it to students through teaching and learning. Learning as a process of giving knowledge from the teacher to students to create the formation of attitudes and behavior in a better direction. Following what was stated by that learning is the assistance provided by 


\section{Mudarrisa: Jurnal Kajian Pendidikan Islam, Vol. 12, No. 1, 2020}

educators so that the process of acquisition of knowledge and knowledge, mastery of skills and behavior, and the formation of attitudes and beliefs in students (Sujana: 2012). Through the learning process, students' abilities can be developed if the learning activities are carried out by directing students to find concepts, not through acceptance of formation from the teacher. Social Sciences (IPS) learning is a science that studies events related to social sciences. In line with Nurkholiq suggested that IPS is an incarnation of an interdisciplinary approach from social science (Nurkholiq: 2016). IPS was different from other subjects. A teacher who teaches social studies subjects must be able to design learning activities by learning models and students' initial knowledge with research activities that can clarify the concepts to be learned.

Social studies is a vital subject and have a great influence. Leaving aside social studies subjects is the same as setting aside students' social life. The impact is like juvenile delinquency that is leading to criminal acts in school-age often occur, fights between students, and even among students. This condition is a challenge for the world of education and needs to be used as a rationale for the need for innovation in social studies learning (Puspitasari, 2016). The innovation made more precisely is on how to make these social studies subjects liked by students. Alan J. Singer (2003) reports that feelings of inferiority and frustration often descend on social studies teachers in the United States where the country is the originator of the emergence of social studies or social sciences curriculum (Birsyada, 2014). 
The saturation of social studies learning is also felt by students and teachers in Indonesia, the view of the construction of society in Indonesia to date still many assume that social studies are only rote, and there is almost no allure for learning (Birsyada, 2014). In social studies learning students are forced to remember various information without being required to understand and find that information based on their potential. This will have an impact on students who will have difficulty in understanding and memorizing subject matter and feeling easily bored (Al Ghazali et al., 2016). This anxiety was felt by Hariata et al (2017) that his research was motivated by observations that showed that one of the subjects that were monotonous and less attractive to students was IPS. Thus, it was necessary to do innovations learning in social studies subjects that aim to make social studies learning attractive by students as learners or teachers as teachers.

The observations were done at SDN Salamjajar, Sumedang Region, in West Java, Indonesia. The learning process at the elementary school level is still teacher-centered. Especially, the concept was conveyed by the teacher and is considered too difficult for students to understand if the lecture method is still used. Especially if the lecture method is too dominant in the learning process. From the results of daily tests of students can also be seen that many student learning outcomes are less than the minimum completeness criteria or Kriteria Ketuntasan Minumum (KKM) that have been implemented in schools. Learning outcomes are the achievement of educational goals in students who follow 


\section{Mudarrisa: Jurnal Kajian Pendidikan Islam, Vol. 12, No. 1, 2020}

the teaching and learning process. According to Purwanto (2008), learning outcomes are "change learning outcomes are "changes in behavior that occur after following the teaching and learning process under educational objectives". Besides, student activities tend to be less active.

It can be concluded, a teacher must be able to direct students to link the material delivered with daily life and use innovative learning models that can develop student creativity and improve student learning outcomes. One innovative learning model is the Connecting Organizing Reflecting Extending (CORE) learning model. The CORE learning model can be used to enable students to build their knowledge. This CORE model combines four important constructivist elements, namely connecting to student knowledge, organizing students' new content (knowledge), providing opportunities for students to reflect on them, and giving students opportunities to expand knowledge (Humaira et al., 2014).

With the implementation of the CORE model, it is expected that social studies learning outcomes can improve. For this reason, a teacher must be able to apply the model with the steps of the CORE model in teaching and learning activities on the material development of production technology. This study is supported by the results of Retnowati and Aqiilah's research (2017) that the results of the study show that CORE learning in paired and small group strategies is effective in terms of the Minimum Criteria for Completion of reasoning ability, achievement, and self-efficacy, but there is no significant difference between the two the grouping strategy. The results of Setiawan's research 
(2018) also state that learning using the CORE learning model can improve students' mathematical communication skills.

Based on the above background, this research conducted a class about the CORE learning model to Enhance Activities and Learning Outcomes of Social Studies Material Development of Production Technology. The novelty of this research is about CORE model for social sciences subjects at the elementary school level.

\section{METHODS}

This research used in this study is Classroom Action Research (CAR). The design used is Kemmis and Mc Taggart is known as the spiral model. The research was located at SDN Salamjajar, Cisitu District, Sumedang region, West Java, Indonesia. The subjects in this study were the $4^{\text {th }}$-grade students of SDN Salamjajar, totaling 23 students. Data collection techniques used in this study were the observation of student activities, observation of teacher performance, learning achievement tests, and documentation.

\section{DISCUSSION}

\section{Results}

The results of this study in the form of student activity data and student learning outcomes in the initial data stage, cycle I, and cycle II. To find out the comparison of the results of student activities from the initial data to the second cycle shown in the following Tabel 1. 
Tabel 1. Comparison of Student Learning Activities from the Initial Data to Cycle II

\begin{tabular}{llll}
\hline Data & $\begin{array}{l}\text { Visual } \\
\text { Activity }\end{array}$ & $\begin{array}{l}\text { Oral } \\
\text { Activities }\end{array}$ & Listening activity \\
\hline Preliminary data & $64.1 \%$ & $56.4 \%$ & $61.5 \%$ \\
\hline Cycle I & $71.8 \%$ & $69.2 \%$ & $77.0 \%$ \\
\hline Cycle II & $83.3 \%$ & $81.4 \%$ & $83.3 \%$ \\
\hline
\end{tabular}

Based on Tabel 1, it can be seen that student activity has increased from the initial data to the second cycle. The aspects assessed in student activities are visual, verbal, and listening activities. In the second cycle, data on the results of student activities have reached the expected criteria with a limit on the achievement of the average student activity in one class that is $80.0 \%$ with the interpretation as good criteria.

The learning outcomes data was taken by using a written test instrument with KKM which is amount 70 exacta. The research will be said to be successful if students who score above KKM are more than 70 as seen in Table 2.

Tabel 2. Data on Student Learning Outcomes from the Initial Data to Cycle II

\begin{tabular}{lllll}
\hline Data & $\begin{array}{l}\text { Highest } \\
\text { score }\end{array}$ & $\begin{array}{l}\text { Lowest } \\
\text { Score }\end{array}$ & $\begin{array}{l}\text { Number of Students } \\
\text { Completed }\end{array}$ & Percentage \\
\hline $\begin{array}{l}\text { Preliminary } \\
\text { data }\end{array}$ & 80 & 50 & 6 & $46.1 \%$ \\
\hline Cycle I & 80 & 50 & 9 & $69.2 \%$ \\
\hline Cycle II & 90 & 60 & 12 & $92.3 \%$ \\
\hline
\end{tabular}

Based on Table 2, it can be concluded that student learning outcomes have reached the expected target in the second cycle with the percentage of students who scored above the KKM of $92.3 \%$. The presentation of the comparative data increased activity data and student 
Mudarrisa: Jurnal Kajian Pendidikan Islam, Vol. 12, No. 1, 2020

learning outcomes in a graphical form that can be seen in Figure 4 and Figure 2.

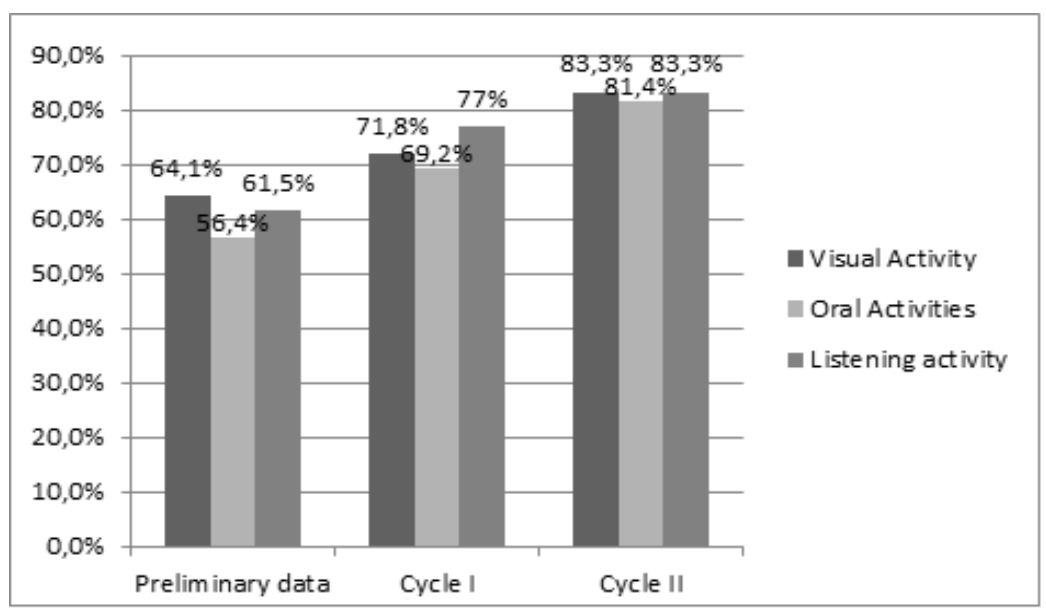

Figure 4. Student Learning Activities from the Initial Data to Cycle II

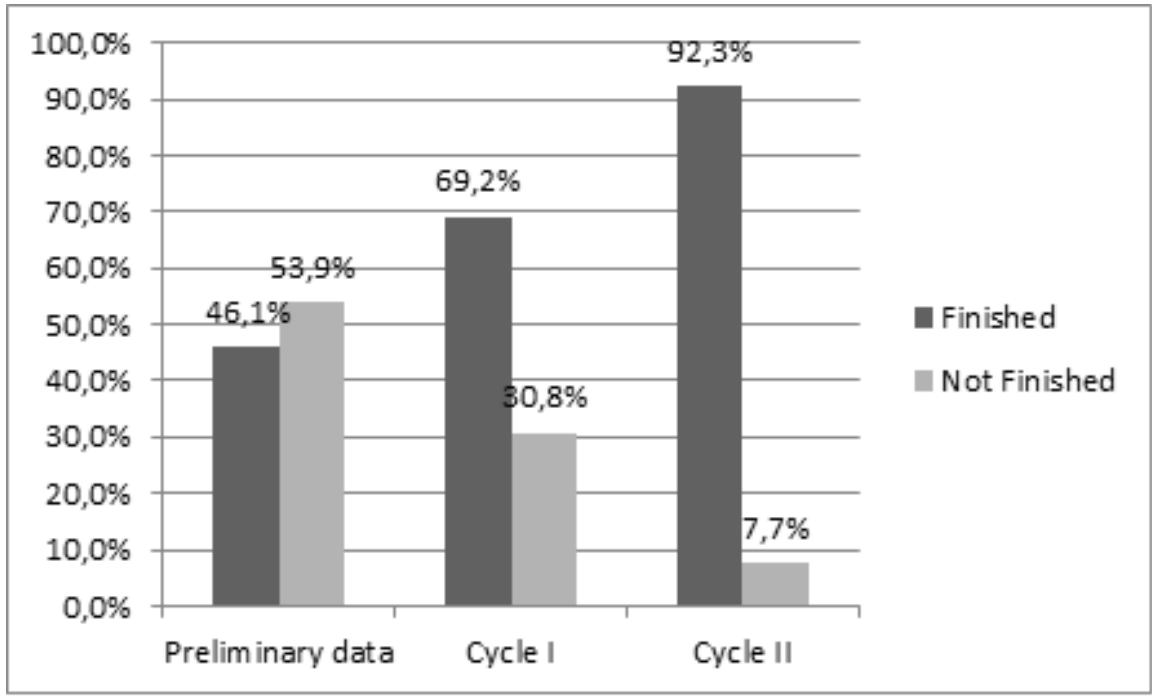

Figure 5. Student Learning Outcomes from the Initial Data to Cycle II 


\section{Mudarrisa: Jurnal Kajian Pendidikan Islam, Vol. 12, No. 1, 2020}

The results of this study showed that student activities reached a percentage of $80.0 \%$ and $70.0 \%$ of learning outcomes. Thus, it could be stated that this study was terminated until the second cycle because it had reached the expected criteria. The development of the learning process occurred. Every process had some different criteria. The teacher must be able to teach students with various skills to get better grades than before.

\section{Analysis}

The Process of Using the CORE Model

The process of using the CORE model developed in this research is to help students actively learn and analyze the real world of social studies learning in the material development of production technology in 4thgrade students at SDN Salamjajar, Cisitu District, Sumedang region, West Java, Indonesia in 2016/2017 school year. The learning material component is adjusted to the competency standards, basic competencies, indicators, and learning objectives.

Based on observations of student activities, it appears that aspects of visual activities, oral activities, and listening activities of students in following the learning process have increased. In the first cycle, the percentage and interpretation of the three aspects achieved were visual aspects $71.8 \%$ (good); $69.2 \%$ oral aspects (good); and $77.0 \%$ (good) listening activities. In cycle II, student activities were very good and under expected targets, because the percentage and interpretation of the three aspects achieved were visual aspects of $83.3 \%$ (very good), aspects of oral activities $81.4 \%$ (very good) and aspects of listening activities $83.3 \%$ (very 
good). It proved that CORE models increase student activities. Supported by Aryati et al (2017), most of the students gave their positive responses to mathematics learning by using the CORE model. In another, Ansori (2014) showed the average score of student activities in the learning process has increased in amount 2.075 with a fairly active category in the first cycle while in the second cycle increased with an average value of student activity of amount 2.99 with an active category. Thus, it can be concluded that increasing student activity in social studies learning using the CORE Model is also supported by the results of research by Aryati et al and Ansori that using the same model can increase student activity even on different subjects.

Related to teacher performance in carrying out the process of using the CORE model, the findings obtained are facilitating teacher performance and can reduce the teacher's role that is too dominant in the learning process. The use of the CORE model in social studies learning in the material development of production technology enables students to learn actively, to create optimal learning conditions and situations. The use of the CORE model makes learning activities more student-centered. Based on observations of the performance of teachers in implementing learning, the results obtained that the first cycle as a whole reached a percentage of $77.0 \%$. The teachers have implemented $77.0 \%$ of all aspects assessed in implementing learning. Then, the performance of teachers in the second cycle has reached $88.3 \%$ of all aspects assessed and included very good and optimal interpretation. Thus, it can be stated that the 
performance of the teacher in the implementation of learning cycle II action has reached the specified target.

Based on the findings described above, it can be said that the process of using the CORE model can improve student learning activities on the material development of production technology in grade IV students at SDN Salamjajar, Cisitu District, Sumedang region in 2016/2017 school year. Thus, the formulation of the problems raised in this study can be answered and tested properly.

Results of Using the CORE Model

Student learning activities on aspects of visual activities, oral activities, and listening activities have increased. In the aspect of visual activities, from the initial data to the first cycle increased from $64.1 \%$ to $71.8 \%$, while from the first cycle to the second cycle there was an increase from $71.8 \%$ to $83.3 \%$. In the oral activity aspect, cycle I showed about increasing $56.4 \%$ to $69.2 \%$, while from the first cycle to the second cycle there was an increase from $69.2 \%$ to $81.4 \%$. The aspect of listening activities, from the initial data to the first cycle increased from $61.5 \%$ to $77.0 \%$, while from the first cycle to the second cycle there was an increase from $71.8 \%$ to $83.3 \%$.

The final exam increased, this is evident from the increasing number of students who completed, the percentage of completeness, and the average value. The magnitude of the increase in the percentage of mastery learning from the initial data to the first cycle increased from $46.1 \%$ to $69.2 \%$, while from the first cycle to the second cycle an increase 
from $69.2 \%$ to $92.3 \%$ of students who completed. The CORE model has used widely in some research. They found a practical framework of the effect of the CORE model in the learning process. As a study conducted by Muizaddin and Santoso (2016), the CORE model gave improving learning outcomes in office administration subjects. In this research, it is proven that the application of the CORE model in improving student learning outcomes has increased. A similar opinion was expressed by Safitri et al (2014) that the application of the CORE model can increase the creativity and learning outcomes of History with the results in the first cycle of cognitive learning outcomes obtained a percentage of $70.96 \%$, in cycle II it increased $9.09 \%$ to $77.41 \%$ in cycle 3 it increased $8.34-83.87 \%$. Beniasih et al (2015) suggested that the results of his research showed a comparison of average science learning outcomes of students who were taught with CORE models assisted by concrete media larger than students who were taught with conventional models (23.36 > 19.06). It could be concluded that student learning outcomes both from different subjects such as Natural Sciences and History in low classes, as well as subjects introductory to office administration in high class can be improved using the CORE models.

Besides improving learning outcomes, the CORE models can also improve understanding such as mathematical understanding and understanding of students' science concepts. Improved mathematical understanding is evidenced by research conducted by Deswita et al (2018) that based on data analysis, it was found that increased mathematical 
communication skills of students who obtained CORE learning models with a scientific approach were better than students who obtained normal learning. While the increase in understanding of the concept of science is proven by research Subarjo et al (2014), the comparison of the results of the calculation of the average understanding of science concepts of students who follow learning with the Core model is 33.67 greater than the average understanding of science concepts of students who followed the conventional model of learning were 26.23. Based on the research results of Deswita et al and Subarjo et al above, it can be concluded that the CORE models can also improve student understanding of both Mathematical Understanding and Science Concepts. These results indicate that the CORE model has advantages in increasing the potential of students both in terms of student learning outcomes and understanding.

\section{CONCLUSION}

Based on the results of classroom action research (PTK) that has been carried out through the use of the CORE models in social studies learning on the material development of production technology in $4^{\text {th }}$-grade students at SDN Salamjajar, Cisitu District, Sumedang region, it can be concluded as follows. Based on observations of student activities, it appears that aspects of visual activities, oral activities, and listening activities of students in following the learning process have increased. In cycle I, the percentage and interpretation of the three aspects achieved 
were visual aspects in percentages $71.8 \%$ (good); 69.2\% oral aspects (good); and $77.0 \%$ (good) listening activities. In cycle II, student activities were very good and by the expected targets because the percentage and interpretation of the three aspects achieved were visual aspects of $83.3 \%$ (very good), aspects of oral activities $81.4 \%$ (very good ) and aspects of listening activities $83.3 \%$ (very good). Based on observations of the performance of teachers in implementing learning, the results obtained that the first cycle as a whole reached $77.0 \%$. That is, teachers have implemented $77.0 \%$ of all aspects assessed in implementing learning. Then, the performance of teachers in the second cycle has reached $88.3 \%$ of all aspects assessed and included very good and optimal interpretation.

Thus, it can be stated that the performance of the teacher in the implementation of learning cycle II action has reached the specified target. Student final test results have increased, this is evident from the increasing number of students who completed, the percentage of completeness, and the average value. The magnitude of the increase in the percentage of mastery learning from the initial data to the first cycle increased from $46.1-69.2 \%$, while from the first cycle to the second cycle an increase from $69.2-92.3 \%$ of students who completed. Thus, it could be stated that the CORE models can improve student learning outcomes towards social studies learning on the material development of production technology in $4^{\text {th }}$ grade students at SDN Salamjajar, Cisitu District, Sumedang Region, West Java province, Indonesia. 


\section{Mudarrisa: Jurnal Kajian Pendidikan Islam, Vol. 12, No. 1, 2020}

\section{REFERENCES}

Al Ghazali, M. I., Hanifah, N., \& Sudin, A. Penerapan Media KCS (Komik Cerita Sejarah) Pada Materi Tokoh-Tokoh Sejarah Pada Masa Hindu-Budha, Dan Islam Di Indonesia Untuk Meningkatkan Hasil Belajar Siswa Kelas V. Jurnal Pena Ilmiah, 1(1), 661-670. https://ejournal.upi.edu/index.php/penailmiah/article/view/3073 /pdf.

Ansori, M. (2014). Implementasi Pembelajaran CORE (Connecting, Organizing, Reflecting, Extending) pada Materi Turunan Fungsi untuk Meningkatkan Aktivitas dan Kemampuan Pemecahan Masalah Siswa Kelas XI IPA 1 SMAN1 Jerowaru. Media Pendidikan Matematika, 2(2), 141-150.

Aryati, T. A., Santika, T., \& Kartika, H. (2017). Pengaruh Model Pembelajaran CORE (Conecting, Organizing, Reflecting, Extending) terhadap Kemampuan Koneksi Matematis Siswa SMP Kelas VIII. Sesiomadika, 517-525.

Beniasih, N. M. A., Suarjana, I. M., \& Rati, N. W. (2015). Pengaruh Model Pembelajaran CORE Berbantuan Media Konkret Terhadap Hasil Belajar IPA Siswa Kelas V SD. MIMBAR PGSD, Undiksha, 3(1). Birsyada, M. I. (2014). Pengembangan Model Pembelajaran IPS dengan Pendekatan Konstruktivisme di Sekolah. Forum Ilmu Sosial, 41(2).

Deswita, R. (2015). Penerapan Model Pembelajaran ConnectingOrganizing-Reflecting-Extending (Core) Dengan Pendekatan Scientific Untuk Meningkatkan Kemampuan Komunikasi Dan Koneksi Matematis Serta Self-Efficacy Siswa SMP: Studi Kuasi Eksperimen pada Salah Satu SMP Negeri di Provinsi Jambi, Doctoral dissertation, Universitas Pendidikan Indonesia).

Hariata, I. N. N., Pudjawan, K., \& Margunayasa, I. G. (2017). Pengaruh Model Pembelajaran Problem Based Instruction Berbantuan Media Powerpoint Terhadap Hasil Belajar IPS, Mimbar pgsd Undiksha, $5(2)$. 
Humaira, F. Al, Suherman, \& Jazwinarti. (2014). Penerapan Model Pembelajaran CORE pada Pembelajaran Matematika Siswa Kelas X SMAN 9 Padang. Jurnal Pendidikan Matematika, 3(1), 31-37.

Nurkholiq, R. (2016). Efektifitas Penerapan Metode Sosiodrama Meningkatkan Kecerdasan Kinestetik Siswa dalam Pembelajaran IPS. International Journal Pedagogy of Social Studies, 1(1), 1-18. https://doi.org/https://doi.org/10.17509/ijposs.v1i1.2087.

Maulana.(2011). Dasar-DasarKeilmuandanPembelajaranMatematika Sequel 1.Subang: Royyan Press.

Muizaddin, R., \& Santoso, B. (2016). Model pembelajaran core sebagai sarana dalam meningkatan hasil belajar siswa, Jurnal Pendidikan Manajemen Perkantoran, 1(1), $224-232 . \mathrm{h}$

Nurkholiq, R. (2016). Efektifitas Penerapan Metode Sosiodrama Meningkatkan Kecerdasan Kinestetik Siswa dalam Pembelajaran IPS. International Journal Pedagogy of Social Studies, 1(1), 1-18. https://doi.org/https://doi.org/10.17509/ijposs.v1i1.2087.

Purwanto, (2008) Evaluasi Hasil Belajar. Surakarta: Pustaka Pelajar.

Puspitasari, E. (2016). Inovasi Pembelajaran Ilmu Pengetahuan Sosial. Edueksos: Jurnal Pendidikan Sosial EF Ekonomi, 3(1).

Reni Fahdini, Ence Mulyadi, Deni Suhandani, J. (2014). Identifikasi Kompetensi Guru sebagai Cerminan Profesionalisme Tenaga Pendidik di Kabupaten Sumedang. Mimbar Sekolah Dasar, 1(1), 33-42. https://doi.org/https://doi.org/10.17509/mimbarsd.v1i1.1362.

Reni Fahdini, Ence Mulyadi, Deni Suhandani, J. (2014). Identifikasi Kompetensi Guru sebagai Cerminan Profesionalisme Tenaga Pendidik di Kabupaten Sumedang. Mimbar Sekolah Dasar, 1(1), 33-42. $\quad$ https://doi.org/https://doi.org/10.17509/mimbarsd.v1i1.1362. 
Safitri, D., Handayani, S., \& Umamah, N. (2014). Penerapan Model Connecting, Organizing, Reflecting, dan Extending (CORE) Untuk Meningkatkan Kreativitas dan Hasil Belajar Sejarah Peserta Didik Kelas X3 SMAN 1 Bangorejo Tahun Ajaran 2013/2014. Jurnal Edukasi, 10-14.

Setiawan, G. (2018). Penerapan Model Pembelajaran ConnectingOerganizing-Reflecting-Extending (CORE) Untuk Meningkatkan Kemampuan Komunikasi Dan Koneksi Matematis Siswa Serta Disposisi Matematik Pada Siswa SMA, Doctoral dissertation, Universitas Pasundan, Bandung.

Subarjo, M. D. P., Sudhita, I. W. R., \& Suarjana, I. M. (2014). Pengaruh model CORE terhadap pemahaman konsep IPA siswa kelas V di gugus I NAkula Kecamatan Negara Kabupaten Jembrana. Mimbar PGSD Undiksha, 2(1).

Sujana, Atep. (2012). Pendidikan IPA TeoridanPraktik.Sumedang: Rizal Nur. 